\title{
Fengselslivet som en livstruende byrde
}

\author{
Av Yngve Hammerlin
}

\section{I sin tale Ved en grav skrev Søren Kierkegaard at døden er en påminnelse om livets alvor. Hva er ikke da selvmordet? - og et selvmord i et fengsel?}

2013 VAR ET DYSTERT OG RYSTENDE ÅR for norsk fengselsvesen: Elleve fanger hadde brutt livet - alle i varetekt. Det var nesten dobbelt så mange som de verste årene i perioden 1956-2012. Det skapte uro i etaten: Var økningen tilfeldig, eller avspeilte den en tendens?

Den tidligere ekspedisjonssief i Kriminalomsorgen R.B. Wegner advarte mot bare å være opptatt av antallet selvmordsdøde i fengsel. Ethvert selvmord er et selvmord for mye, betonte han.

Det betyr også at selvmordsproblematikken må forstås helhetlig relatert til selvmordstanker, selvmordsforsøk og selvskader. Men fokus må òg rettes mot den fengsledes levekår og livssituasjon utenfor murene og hans/hennes eksistensielle slitasje og lidelse som fengslet. Det er viktig å se mennesket i fengsel og fengslet $i$ mennesket, med et blikk for fengselslivet som byrde og ikke minst den eksistensielle belastningen som Stein Lillevolden har betegnet «når angsten tar fanger» (2017).

I denne kronikken gir jeg først et grovskåret bilde av fengsels-Norge og hvilke ideologiske grunnprinsipper som er rammeverket for fengselshverdagen. Deretter presenterer jeg selvmordsproblematikken i perioden 1990-2016. Som basis bruker jeg særlig våre studier og rapporter som er utarbeidet i periodene 1988 til 2007, samt boka mi om selvmordsforebyggende arbeid i fengslene fra 2009; i tillegg bygger jeg videre på et par artikler som jeg skrev i Suicidologi i 2010 (Hammerlin, 2010a,b) og Psyke \& Logos i 2015 (Hammerlin, 2015a,b) samt en statistisk oversiktsstudie fra perioden 2008 2016/2016 (Hammerlin og Grav, 2015a). Jeg avslutter med fagetiske og kritiske refleksjoner relatert til et problemknippe.

\section{Fengselssystemets ideologiske rammeverk}

Fengselssystemet i Norge representerer et institusjonelt mangfold fra de mest sikkerhetskompakte systemene til de lite fengselsaktige institusionene (åpne soningsformer). Offisielt kategoriseres fengslene som fengsel med høy sikkerhet, særlig høy sikkerhet, lavere sikkerhet og overgangsboliger. Fengslene grupperes og ordnes etter institusjonsfunksionelle oppgaver. Ca. 94 prosent av fangebefolkningen er menn. Det er fem kvinnefengsler i Norge, men det finnes også åtte fengsler med separate avdelinger for menn og kvinner. Videre er det fengsler og avdelinger for varetekt, dom og forvaring. Det er også nylig etablert to barne- og ungdomsfengsler: I Ungdomsenhet vest (Bjørgvin) fengsles både jenter og gutter i alder 15-18 år; i Ungdomsenhet øst (Eidsvoll) sitter bare gutter. I tillegg er det et eget fengsel for utlendinger, skiønt utenlandske fanger sitter i de fleste norske fengsler.

I 2016 var giennomsnittlig antall fengslede pr dag 3850 og i 2015, 3746. I 2016 satt ca. $66 \%$ av fangene i fengsler med høy sikkerhet (lukket fengsel) og ca. 34 \% i fengsler med lavere sikkerhet (åpent fengsel). Varetektsfanger utgiorde da ca. $30 \%$ av fangebefolkningen (men er i 2017 gått noe ned).

Fengselssystemets virksomhetsrammer og praksisformer er historisk og analytisk sett sementert og utformet med en grunntanke i to ideologiske grunnkomponenter (Hammerlin, 1994; 2004; 2008): 


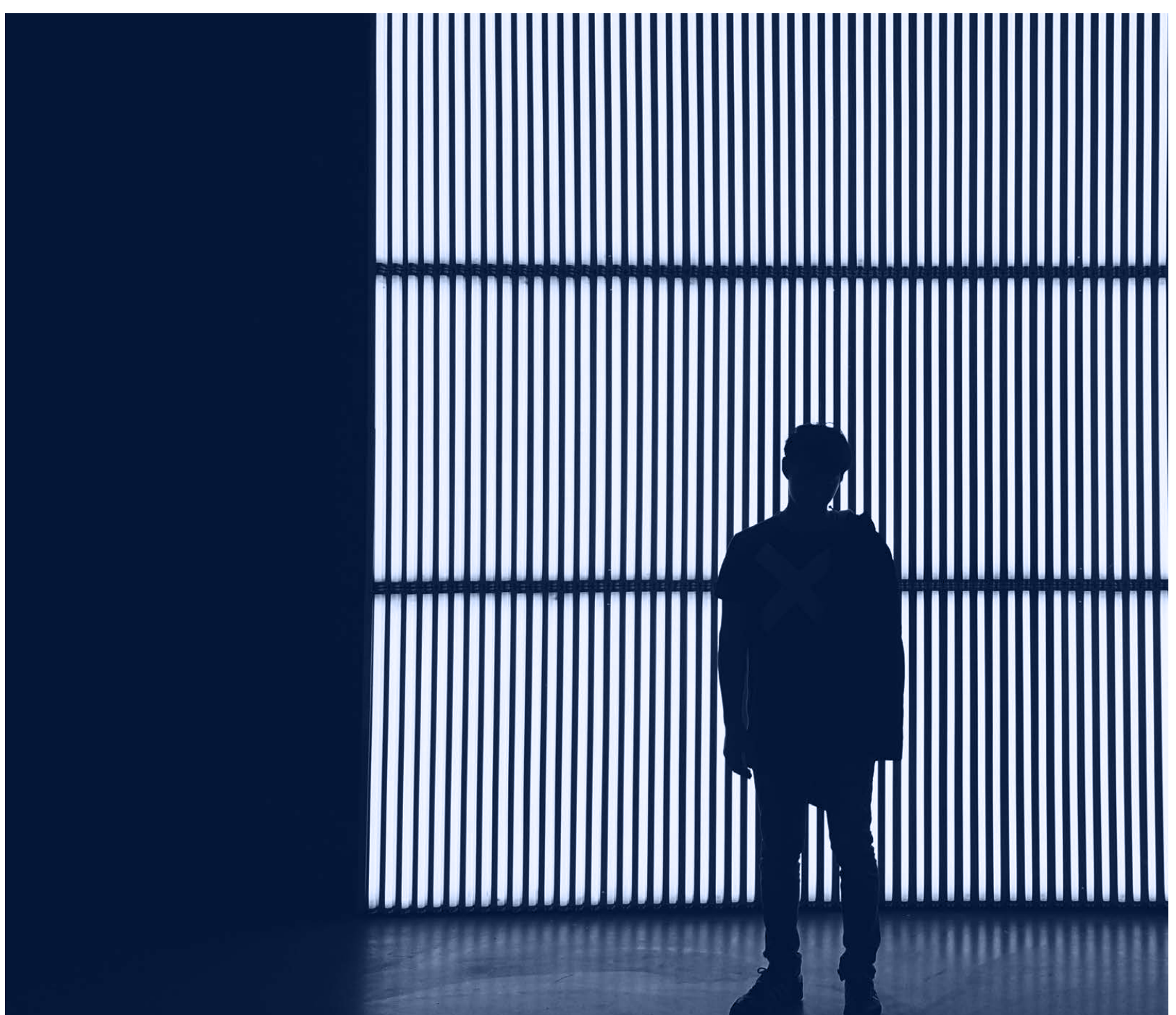

For det første (i) er fengselssystemet preget av en frihetsberøvende og sikkerhetsfokusert straffeideologi med en straffegiennomføring der særlig høysikkerhetsfengslene har en svært streng kontroll-, disiplineringsog sikkerhetsstrategi. De nedfelles og kommer til uttrykk i fengselshverdagen og i de materielle, sosiale, organisatoriske, teknologiske og symbolske praksisformene. E. Goffman definerte fengselssystemet som en total institusjon. Jeg anser de mest restriktive og maktbastante fengselssystemene i Norge som repressive og totalitære. Samfunnets behov for sikkerhet, sikkerheten i fengselssystemet og straffegiennomføringen er grunnleggende systemfunksjoner, og sikkerheten er offisielt kategorisert i tre typer: statisk sikkerhet (ringmur, kamera, alarmanlegg m.m.), administrativ sikkerhet og dynamisk sikkerhet (giennom interaksjon og daglig samvær). De består av åpne og skjulte former (se også Mathiesen, 1978; Metz m.fl., 2017).

For det andre består straffegiennomføringen av en (ii) rehabiliteringsideologi og en omsorgsideologi som kan deles inn i to innsatsformer:

Den ene a) omfatter forskjelligartede tiltak samt hielpe- og omsorgrelaterte opplegg som skal kompensere eller dempe fengslingens skadevirkninger. De negative virkningene av fengslingen er både helsemessige, eksistensielle og sosiale. På basis av tidligere fengselsforskning (G.M. Sykes, I. Galtung og T. Mathiesen) og mine egne studier av fengselshverdagen og fangenes fengslingssituasjon, utviklet jeg på 1980-tallet det jeg har kalt Fangenes tapsliste konkretisert til norske forhold (Hammerlin 1987/1994, 2008, 2015, 2019 in print). Tapslista ajourfører jeg grovt sett hvert femtesjette år. Det giøres på basis av forskjellige fengsels- og praksisfeltstudier og ved samtaler og interviuer med fanger, betienter og andre aktører i systemet. Viktig er òg dokumentstudier. Den første tapslista utarbeidet jeg i 1986/1987, og er sist revidert i 2014/2015 (Hammerlin, 2015a, s.149-152; Hammerlin, 2018/2019). Fangenes 
tapsliste er etterprøvd/videreutviklet bl.a. av psykologene Brekke og Halvorsen i 2004. Tapslista er viktig for å kunne forstå fangenes eksistensielle, sosiale og helsemessige problemer som utvikles eller forsterkes under fengslingen, og er adekvat for hielpe- og omsorgsinnsatser og selvsagt også selvmordsforebyggende arbeid.

Den andre innsatsen b) bygger på en offisiell rehabiliterende integreringsstrategi om tilbakeføring til samfunnet. Dette skal skje relatert til fangenes rettigheter til yrkesopplæring, arbeidserfaring, utdanning, helsemessige tiltak og kulturaktiviteter (importerte tjenester), men også ved tiltak i form av programmer (bl.a. kognitive), samtalegrupper m.m. Kriminalomsorgens målsetting er at fangen skal tilegne seg kunnskaper og handlingskompetanse for å kunne leve et kriminalitetsfritt liv. Etablerte hielpe- og omsorgsfaglige prinsipper er også en del av praksis for det omsorgsideologiske rammeverket. Til disse oppgavene importeres ulike faglige tienester blant annet inn i fengselet (kalt importmodellen).

Straffeideologien, rehabiliteringsideologien og omsorgsideologien må også betraktes som den ideologiske overbygningen for fengselsvirksomheten. Ideelt sett skal dette ideologiske rammeverket avspeile en human fangebehandling, men ideologiene representerer ulike premisser og menneskesyn, og kommer ofte i et spennings- eller motsetningsforhold til hverandre. I og med at frihetsberøvelsen og sikkerhetstiltakene er de grunnleggende og styrende prinsippene, settes også grenser for tiltak knyttet til de rehabiliterings- og omsorgsideologiske innsatsene. Det er flere historiske eksempler på at når sikkerheten trues, innføres skjerpede innstramninger og ulike sanksjons- og differensieringsformer (Hammerlin, 1994; 2004a; 2008; 2012; 2015a; 2018/2019; Hammerlin og Mathiassen, 2006).

Men også en tredje ideologisk styringskomponent (iii) preger fengselshverdagen: økonomisme (samt en ideologisk styringsform som også er påvirket av en økonokratisk grunntenkning, dvs. at politiske mål defineres ut fra deres effekter på okonomien). Etaten preges av effektivitetskrav, belastende innsparinger, nyliberalistiske og utilitaristiske grunntanker, samt krav om nye organisasjons- og ledelsesprinsipper (management-modeller). Mottoet siden 199o-tallet har vært: Mer kriminalomsorg for hver investerte krone. Den opprinnelige dikotomien over (i) og (ii) blir sammen med den tredje komponenten (iii) en motsetningsfylt trikotomi som forsterker spenningsforholdet mellom formåls- og verdirasjonelle krav og mellom idealer og realiteter (Hammerlin 1994; 2004; 2008; 2015a).

\section{Fengslenes statistiske selvmordsbilde}

De nordiske kriminalomsorgene har et felles definisjonsgrunnlag: Selvmord i anstalter omfatter:

de personer som har dött eller tagit sitt liv inne på anstalten eller inne på häktet [varetekt]. När den intagna själv inne på anstalten eller häktet dör av skadan utanför anstalten eller häktet, t.ex. i sjukhus, räknas även detta som självmord i fängelse respektiva häkte (Nordisk Statistik for kriminalomsorgen).

\section{Selvmordene 1990-2016}

Fra 1990 til og med 2016 har 101 personer brutt livet i norske fengsler - 96 menn og fem kvinner. Antall selvmord varierer fra null til elleve pr. år. Selvmordene har skjedd i 27 fengsler og én overgangsbolig. De lukkede fengslene med høyt sikkerhetsnivå dominerer klart selvmordsbildet; det er få selvmord i de åpne fengselsformene.

Diagrammet under viser selvmordene i varetekt i forhold til det totale antallet selvmord i perioden 1990-2016:

Figur 1. Selvmord i norske fengsler 1990-2016. Varetektens (blå) andel av totalen (rød).

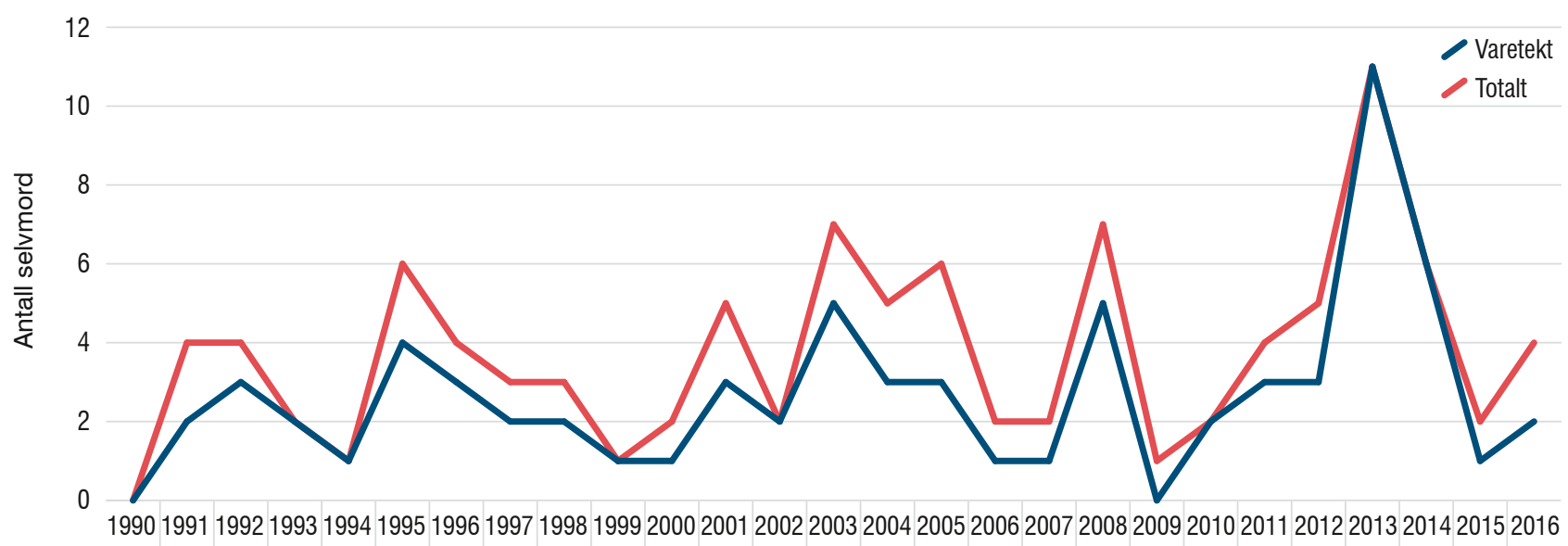

Hammerlin, 2018/2019 (tabellen er basert på våre/mine tidl. studier; nyere tall fra 2010 er gjort i samarbeid med Kriminalomsorgsdirektoratet eller KDI) 
I perioden 1990-2016 ( $\mathrm{n}=101)$ brøt 72 varetektsfanger og 29 domsfanger livet (Hammerlin, 2009, 2015; Hammerlin og Grav, 2015/2016). I hele perioden 1956-2016 ble grovt sett tre av fire selvmord i fengsel giennomfort i varetekt. I 2013 skjedde alle elleve selvmordene i varetekt (ti menn og én kvinne), og det samme gialdt også selvmordene i 2014 (bare menn). I 2016 skjedde to av fire selvmord i varetekt (tre menn og én kvinne). Men selv om selvmord i varetekt dominerer selvmordsbildet, må man ikke glemme at $1 / 4$ av fengselsselvmordene ble giennomfort av domsfanger som brøt livet på ulike tidspunkt under soningen. Vi må derfor studere både fengslings- og livssituasjonen for varetektsfengslede og domssonere for å avdekke forhold som påvirker livsavbruddene.

For tiårene 1956-199o tok få fanger, registrert med utenlandsk statsborgerskap, livet sitt i fengsel. Tallene fra 1990-2016 viser en økning ved at 29 av 101 som brøt livet i denne perioden hadde utenlandsk statsborgerskap (alle menn). De kom fra Litauen, Irak, Afghanistan, Bulgaria, Eritrea, Estland, Kosovo, Kroatia, Nederland, Polen, Somalia, Sveits, Sverige, Sør-Sudan, Tunisia og Iran. Man skal òg merke seg at andelen fanger med utenlandsk statsborgerskap har økt. Mens den på 2000-tallet var på ca.12 prosent, utgiorde den i perioden 2012-2016 ca. 1/3 av fangebefolkningen (Nordisk Statistik, 2018).

Gjennomsnittsalder for dem som brøt livet i 19902016 var ca. 35 år. De yngste var 19 år mens den eldste var 77. Tretten personer ( $22 \%$ ) var under 25 år. Til sammenlikning var halvparten av de selvmordsdøde i 1956-1992 under 25 år. Av fangegruppa som brøt livet på 2000-tallet (fra 2000-2016), var sju i aldersgruppa 50-64, to over 64. Tendensen de siste tiårene er at giennomsnittsalderen på dem som forkorter livet ved selvmord blir høyere. Fra 2008-2016 er giennomsnittet ca. 36-37 år.

Selvmordsmetodene er klart dominert av henging som utgiør tre av fire selvmord blant fanger. Ti prosent skjedde ved kvelning mens resten forkortet livet ved å kutte seg, hoppe fra høyde, tenne på cella, eller ved insulin- og diettstreik. Hengingen eller kvelningen er utført ved hielp av skjerf, skolisse, tøy, bandasje, tau, laken og belte. Opphengingspunktet var bl.a. gitteret, ventilluka, skapdører, toalettdøren, dusjhodet og krok på soilrør.

Tidspunktet for selvmordene viser at mange selvmord giennomføres svært tidlig under fengslingen og kort tid etter innsettelsen. I studien som omfatter perioden 1990-2007, forkortet 42 prosent av 59 fengslede livet ved selvmord i løpet av de første 14 dagene etter innsettelsesdagen: 15 fengslede giorde det i løpet av den første uka, mens 13 av 15 giennomforte selvmordet mellom første og tredje dag etter innsettelsen (inkludert sju personer som brøt livet på innsettelsesdagen/ påløpende dag). I noen fengsler skjer selvmordet meget tidlig, i andre varierer hendelsestidspunktet

\section{En forskjell fra tidligere, er at det er flere (ti personer) som var fengslet over hundre dager for selvmordet ble giennomfort.}

over lenger tid. Selvmordene i 2008-2016 (n:42) tegner samme bildet av handlingstidspunktet. Av de 42 fangene som tok selvmord i perioden brøt ca. $20 \%$ livet i løpet de tre første dagene; fem personer i løpet av det første dognet og nesten $35 \%$ innen de forste åtte dagene. En forskjell fra tidligere, er at det er flere (ti personer) som var fengslet over hundre dager før selvmordet ble giennomført (Hammerlin og Grav, 2015/2016; tallene fra 2000-2016 bygger også på Kriminalomsorgsdirektoratets/KDIs data).

Ser vi på perioden 1990-2016 giennomføres de fleste selvmordene i løpet av natta eller tidlig om morgenen.

Det er vanlig at man registrerer hovedforbrytelsen som personen er siktet eller straffet for ved siste fengsling. Den største gruppa selvmordsdøde i 1990-2007 (i denne perioden forekom totalt 59 selvmord) var fengslet for narkotikarelaterte forbrytelser (24 av 59). Elleve personer var fengslet for drap, drapsforsøk og vold (av dem seks fengslet for drap, en for drapsforsøk og fire for andre typer grov vold); fem var fengslet for sedelighetsforbrytelser og tolv (ca. 20 prosent) for tyveri- og vinningsforbrytelser. Resten var fengslet for andre lovovertredelser (Leer-Salvesen, 1988,2004; Walby, 2004).

Ser vi på selvmord i perioden 2008-2016 avdekkes det samme kriminalitetsbildet: Av de 42 fangene, dominerer legemsvold og voldstrusler. Sju var fengslet for drap, drapsforsøk eller mistenkte for drap (alle døde i varetekt), ti for ulike former for voldsbruk og trusler (åtte av dem døde i varetekt), mens fire satt varetektsfengslet for sedelighetsforbrytelser, to var fengslet for ran. Narkotikaforbrytelser dominerte bildet: Av tolv personer som brøt livet satt tre på dom og ni i varetekt. Fire var fengslet for tyveri, dokumentfalsk o.l. (tre på dom og én i varetekt), mens tre kom under andre lovbruddskategorier.

\section{Levekårsproblemer, sosiale og eksistensielle kriser} For en betydelig gruppe av dem som har giennomført selvmord i fengsel i perioden 1990-2016 er det mangelfull informasjon om den enkeltes levekår og fysiske og psykiske helse. Men på tross av mangelfulle informasjoner, kan et generelt bilde avtegnes. Det er grovt sett temmelig identisk med de helse- og levekårsundersøkelsene som er giort på hele fangebefolkningen på 2000-tallet og i forbindelse med diverse andre fengselsstudier (Fridhov, 1993; Hammerlin og Larsen, 2000; Skardhamar, 2002; Stang et al., 2003; Friestad og Hansen, 2004; Larsen, 2004; Hartvig og Ostberg, 2004; Kjelsberg et al., 2006; Dyb et al., 2006; Rein, 


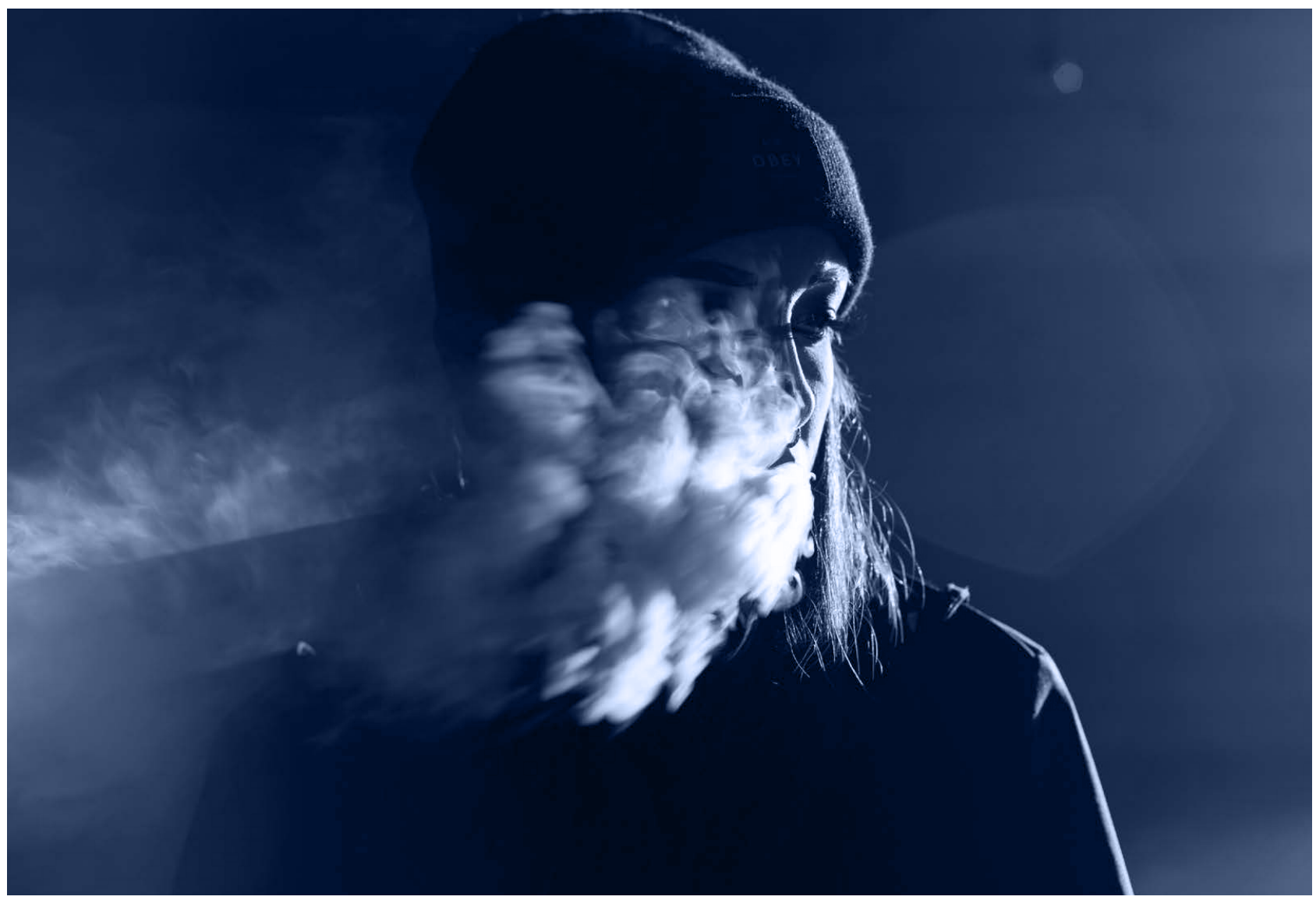

2009; Kjelsberg og Sørland, 2009; Clausen, 2013; Revold, 2015). Vi har imidlertid helt fra de forste studiene på 1980-tallet til nå registrert at en stor gruppe av fengslede som brøt livet sitt hadde sammensatte og komplekse helse- og levekårsproblemer allerede for de ble fengslet. Mange var arbeidsløse eller trygdete, hadde dårlig boforhold og lite skolegang. En stor gruppe var enslige (ugifte, separerte eller skilte). Mange hadde stoff- eller alkoholproblemer, og svært mange hadde flere dommer og fengselsopphold bak seg.

Et lite mindretall av de fengslede som tok livet sitt skilte seg ut ved å ha en annen levekårsprofil. De hadde tilsynelatende levd et integrert liv, hadde god utdannelse og et godt etablerte familie-, arbeids- og boforhold før de begikk en kriminell handling.

Det er særlig to grupper av dem som har brutt livet i fengsel som vi har relativt lite informasioner om: Den ene gruppa er fanger med et annet statsborgerskap som tok livet sitt relativt tidlig under fengslingen og en del personer som har levd et temmelig marginalisert og ustrukturert liv.

En samlet systematisk registrering finnes ikke av hvor mange av de selvmordshandlende fengslede som hadde vært eller var under behandling for psykiske lidelser og sykdom, men etatens rutinemessige registrering viser mer usystematisk at en betydelig gruppe av dem som brøt livet i perioden 1956-1992 og 1990-2016 var registrert med psykiske lidelser/sykdommer og rusproblemer både før og under fengslingen. Om det er flere enn tidligere, er det vanskelig å si noe om fordi systematiske og adekvate studier ikke er giort. Fagpolitisk sett hevdes det imidlertid at fangebefolkningen er sykere enn tidligere. Etaten har også lite informasjoner om mange utenlandske fangers helseproblemer. I Norge er det òg altfor få studier som er giort av psykiske lidelser og psykiske sykdommer som utvikles under fengslingen og som følge av oppholdet. Derimot finnes oversiktsstudier om fangenes generelle psykiske helse som er giort innenfor helsesektoren. Det er særlig psykoselidelser, stemningslidelser med psykosesymptomer og stemningslidelser i kombinasjon med rusmiddelmisbruk og emosjonelt ustabil personlighetsforstyrrelse som trekkes fram. Sammenliknet med allmennbefolkningen er forekomsten av psykose registrert tre ganger så høy i fengslene, mens depresion er ca. 6o prosent høyere (Kjelsberg og Hartvig, 2005, s.13; se også Rasmussen og Levander, 1996; Liebling, 1992; Levander et al., 1997).

Victoria Cramer (2014) har i sin studie Forekomst av psykiske lidelser hos domfelte i norske fengsler i 2011-2013 vist at psykiske lidelser er betydelig høyere for fanger enn for befolkningen ellers. Av 857 domfelte kvinner og menn (av en total fengselspopulasjon på 3650) hadde 92 prosent på undersøkelsestidspunktet tegn på personlighetsforstyrrelser eller psykiske lidelser. 


\section{Det formidles at det er særlig angsten for framtida og stigmatisering som plager, men også de praktiske og sosiale vanskelighetene ved integreringen.}

Totalt 73 prosent var registrert med symptomer på en eller flere personlighetsforstyrrelser, 65 prosent var rusmiddelavhengige før de ble innsatt i fengsel, 42 prosent hadde symptomer på pågående angstlidelse, 23 prosent symptomer på stemningslidelse, mens 4,2 prosent hadde symptomer på pågående psykose. Det er imidlertid en klar begrensning at denne studien ikke omfatter varetektsfanger. Jeg er òg kritisk til at diagnostiseringen ikke er foretatt ved en klinisk undersøkelse, men giennom interviuer ut fra et registreringsskjema. Studien sier også for lite om suicidalitet.

Til sammenlikning har Benjaminsens og Erichsens (2002) studie fra danske fengsler avdekket at 20 prosent av varetektsfangene minst én gang tidligere hadde forsøkt selvmord. Tjue prosent hadde tidligere vært innlagt i psykiatrisk avdeling, 40 prosent hadde alkohol- og stoffproblemer, mens 25 prosent fikk diagnostisert en personlighetsforstyrrelse. Et par prosent av varetektsfangene hadde schizofreni eller andre paranoide lidelser og psykoser. Ifølge forfatterne slet også mange av fangene med rusavhengighetslidelser og somatiske sykdommer. Forfatterne av denne undersøkelsen hevder at fire ukers isolasjon oker risikoen for alvorlig psykisk lidelse 20 ganger.

\section{Selvmord i fengsel er riktignok stedbundet ...}

På basis av mange samtaler med fengslede over flere år, skiller jeg analytisk mellom 'her-og-nå-væren' som fengslet, 'her/der-og-da-væren' som situasjonen og livet for fengslingen - og her/der-og-når-situasjonen etter fengslingen. Situasjonsfilosofisk, virksomhetsteoretisk og eksistensielt sett er dette et analytisk skille som må forstås helhetlig og prosessuelt. Den engelske filosofiprofessoren S. Critchley tydeliggiør det situasionsbetingete tidspunktet i Notes on Suicide på denne måten (2015, s. 76): «This moment, one out of a million millions», og han legger til tidspunktet der han er her og nå «... towards 4.30 p.m. a Thursday afternoon in late November, om East Anglian beach (...)».

Det analytiske skillet har som utgangspunkt å studere her-og-nå-situasjonen som fengslet og dermed den enkeltes væren, tanker, følelser og opplevelser $i$ fengselssituasionen og fengselshverdagen. Men det analytiske perspektivet er også i der-og-da-væren rettet mot tanker og opplevelser den enkelte har med hendelser, situasioner og livsbetingelser for fengslingen. Viktig er også den resterende tida av fengsling og tida etter fengslingen (dvs. den kommende der-og-når-væren/ situasjonen).
Et kjennetegn for mange av fangene som brøt livet er dårlige levekårsbetingelser med en opphopning av helse- og levekårsproblemer før fengslingen. Flere av disse blir i suicidologien (enkeltvis eller samlet sett) også kategorisert som risikofaktorer. Men uten tvil er situasionen som fengslet for mange en stor eksistensiell byrde og som jeg vil komme tilbake til som fengslingens lidelsesproduksion.

Temaet for denne kronikken er ikke selvmord etter fengsling. 1990-2007-undersøkelsen viser imidlertid at en mindre gruppe giennomførte selvmordet like for de skulle løslates. Det formidles at det er særlig angsten for framtida og stigmatisering som plager, men også de praktiske og sosiale vanskelighetene ved integreringen. "Fanget i tilværelsen», har Charlotte Mathiassen kalt denne vanskelige tida (Mathiassen, 2004; 2005).

Det er foretatt altfor få studier i Norge om selvmord og selvmordsnærhet for eks-fanger. Overdødeligheten ved selvmord etter soning er derimot registrert blant annet knyttet til rus-, marginaliserings- og integreringsproblemer (bl.a. Kjelsberg og Laake, 2010; Bukten et al., 2017).

\section{Når fengselsværen produserer lidelse}

Et viktig poeng som må gientas viser at nesten alle selvmordene er giennomført i lukkete fengsler med høyt sikkerhetsnivå - svært få i de åpne soningsformene. Som skrevet over: Grovt sett var tre av fire varetektsfanger mens en av fire var domsfanger. A. Alvarez' (1976) begrep "selvmordets lukkede verden» får derfor en dypere mening sett i lys av fengselssystemers maktkompakte innelukkethet. Selvmord og selvmordsnærhet må derfor studeres strukturelt og eksistensielt ut fra de konkrete fengselsbetingelsene (systemvirksomhetenes innhold og form, samt de objektive sosiomaterielle forholdene). Viktig i analysene er også den enkelte fanges personlige forhold til livssituasionen, fengselsværen og cellelivet. Grunnleggende er (som vist over) òg personens sosiale liv og fysiske og psykiske konstitusion. Fangenes tapsliste blir derfor ett av flere viktige analyseverktøy. Beveggrunnen for selvmordet kan imidlertid være en annen enn selve fengslingen, skjønt fengselssituasionen ofte er en forsterkende og utløsende faktor for selvmordet. For enkelte kan fengselsoppholdet dempe selvmordstrangen.

I og giennom mine og kollegers mange samtaler og interviuer med fengslede fra 1980-tallet til nå, og da særlig i forbindelse med de ulike studier om fengselshverdagen og situasionen som fengslet (relatert til voldsstudier, selvmordsstudier, konkrete fengselsstudier, samtaler om Fangenes tapsliste mm.) forteller mange fanger om en grunnstemning av en avmektig håpløshet som følge av den sosiale isolasjonen, systemets repressive struktur og fortvilelse over den kriminelle hendelsen som de hadde begått. Foruten at arrestasjonen, forhøret og arrestoppholdet erfares byrdefullt, kan varetekten og isolasjonen oppleves sjokkartet, 
ydmykende, angsttung og traumatisk (se blant flere Andersen et al., 1994, 1997; Sestoft, 1997; Betænkning, 1998, Hammerlin og Larsen, 2000; Gamman, 1995; Stang et al., 2003; Stang og Østerberg, 2006; Rein, 2009; Rua, 2012; Hytten, 2012; Scharff Smith et al., 2013; Rundskriv 29.12.1997; Danielsen og Karlsen, 2007 - samt Hammerlins nevnte selvmords- og voldsstudier).

Her-og-nå-situasionen som isolert og innesperret kan for mange kjennes klaustrofobisk og integritetskrenkende. Flere innsatte viser til fengslets inneklemte materielle struktur, et semiotisk felt av tegn som hele tida materialiserer det maktfulle. Lillevolden (2017, s. 109) tydeliggiør det slik: Varetekt og isolasion er «bokstavelig støpt i betong - hvor selvmordet i varetekt blir presset frem av den totale avmakten». Ikke bare det: Enkelte fanger som soner tungt isolerer seg også fra fellesskapet (se Hammerlin og Larsen, 2000). En fange beskrev i en samtale med meg varetektsituasjonen, isolasjonen, den eksistensielle krisen og sine selvmordstanker på følgende måte: "Alt var svart, jeg var mer eller mindre i koma; jeg så jo at det var ledninger der» (underforstått - en mulighet til å bryte livet).

Bruken av varetektinstituttet og isolasjon er skarpt kritisert. Dagbladet Information (i artikkelen «Sejlivet isolation» 9.12/2005) betegnet isolasjonsfengslingen som ikke et «retssamfund værdigt» og en «skamplæt». «Nedbryting av fanger», «uvisshetens dødsdans», «avmaktens korridorer», kaller Lillevolden (2014) bruken av isolasion og varetekt. Han, som mange andre, kritiserer også politikerne for mangelfull oppfølging av den europeiske torturovervåkingskomiteens (CPT) kritikk av varetektinstituttet og isolasjon i Norge.

Men isolasionsproblematikken er ikke bare sikkerhetsforanstaltninger og reguleringer med delvis eller fullstendig isolasjon. Å fengsle er en institusjonell isolasjon og sosial avsondring fra omverdenen og må studeres i en mer utvidet betydning og helhetlig kontekst. Den uttrykkes i fengslenes sosiomaterielle organisering og ved fengselshverdagens virksomhetsformer og rutiner. Tre fanger, fengslet på lange dommer, tydeliggiorde det utvidete isolasionsperspektivet for meg på denne måten: «Isolasionen opplever jeg også giennom betjentenes væremåte», sa den ene. "Isolasion er summen av alle konkrete småting som stenger meg i fengselshverdagen», la en annen til. En tredje, som viste meg cella si i et av de mest moderne fengslene vi har, pekte på cellevinduet og sa: «Riktignok er det uten sprinkler, men ser jeg ut, ser jeg to ting: To tredjedeler av vinduet er en grå mur, en tredjedel er noen tretopper» - nok et uttrykk for at cellelivet blir inneklemt og knugende.

Selv om mange domsfanger forteller om hvordan de institusionaliseres og tilpasser seg fengselslivet, forteller de også om hvordan de opplever den innelåste og frihetsberøvende fengselstilværelsen. Fortellingene vitner om mange eksistensielle kriser og belastninger. På tross av at betjenter og andre følger opp med omsorgs- og hielpetiltak, sliter fengsels- og cellelivet på de innsatte.

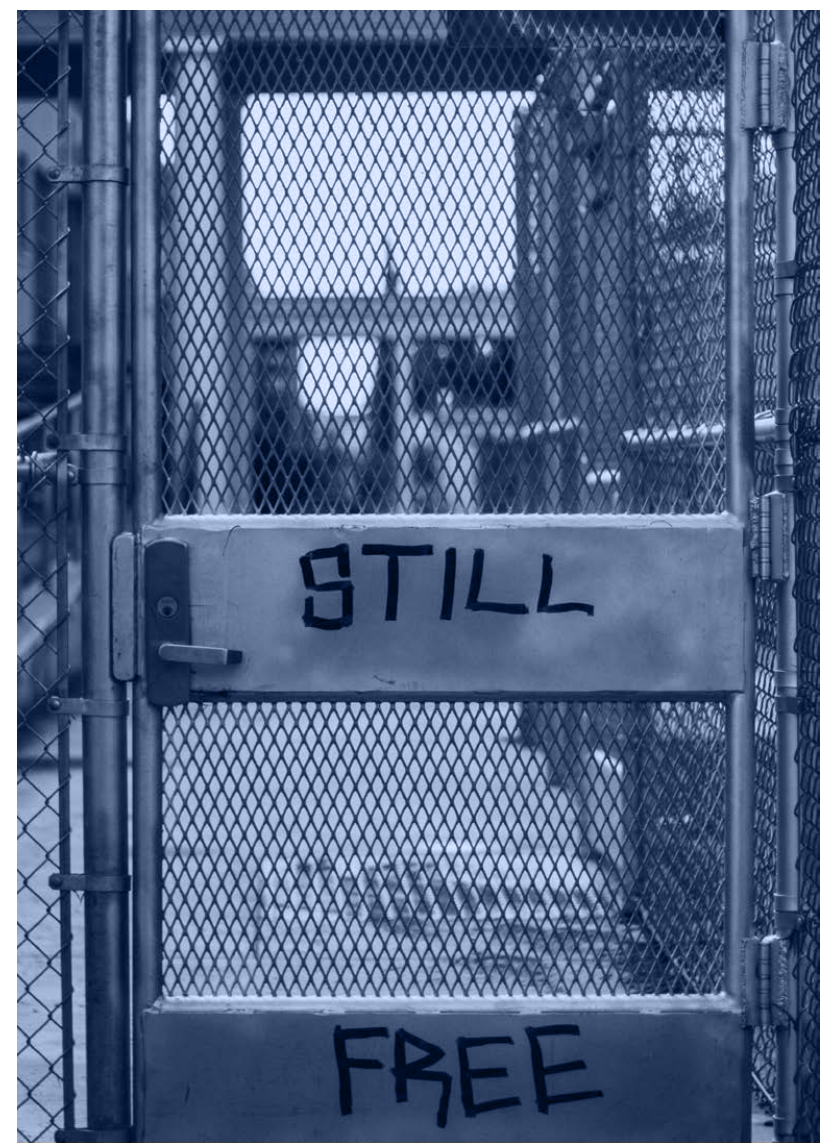

Straffens formål er definert som «et onde som staten tilføyer en lovovertreder på grunn av lovovertredelsen, i den hensikt at han skal føle det som et onde» (Andenæs, 1974). Høyesterett sluttet seg til definisjonen i 1977 (Norsk Rettstidende, 1977) - men som Nils Christie (1982) og Espen Schaanning (2009) har tydeliggiort, må «det onde» som tilføyes også studeres konkret som påføring av smerte og lidelse.

Mange fanger gir uttrykk for at det å miste friheten og oppleve tap av integritet og selvbestemmelse er en svært kvestende påkjenning. De bekrefter også Fangenes tapsliste og viser til en rekke grunnleggende sosiale, relasjonelle, tinglige, økonomiske, helsemessige og eksistensielle tap. Tapene slår riktignok ut på forskjellig måte fra individ til individ, og noen tap kan i perioder være viktigere enn andre. Flere sier også at de ofte føler seg sosialt nedvurderte og at deres integritet krenkes (Hammerlin, 2008; 2009; Hammerlin og Larsen, 2000; Hammerlin og Mathiassen, 2006). Et fengselsopphold blir ofte for flere en bekreftelse på aggregert «personlig mislykkethet». Enkelte fanger sliter dessuten med store gieldsbyrder og noen hevder å bli «truet på livet» fra kriminelle miljøer. Mange fanger trekker også fram at det er en stor belastning å være fengslet sammen 
med mennesker de ellers ikke ville hatt kontakt med. Atter andre har mistet livsmotet fordi framtida synes fastlåst, truende og håpløs. Kort og godt: Når flere av disse tapene smelter sammen, kan det føre til en $ø \mathrm{kt}$ selvmordsrisiko. For mange er byrden en prosessuell problemsammenfiltring der eksistensielle, sosiale, psykiske og somatiske belastninger utvikles, forsterkes eller avtar under fengslingen.

I samtaler vi har hatt med utenlandske fanger forteller flere at de sliter med ensomhet og usikkerhet (Hammerlin og Mathiassen, 2006). Betjenter forteller òg om store kommunikasionsproblemer siden mange fengslede bare behersker et språk som få eller ingen betjenter kan. Dette forvansker kommunikasjonen om den enkeltes situasjon, helse og behov. Vanskelig er det å få tak i tolker, og problematisk er det å forstå et smertespråk preget av en helt annen kultur.

\section{Selvmordshandlingene - motiver og handlingsmål} Selvmord i fengslene har varierte forklaringsgrunner, ulike mål, meninger og betydninger. I noen tilfeller kjenner vi til beslutningsgrunnene og motivene til den enkelte. Ofte har det vært flere motiver, slik undersøkelsene fra perioden 1956-2007 viser. De må forstås ut fra personens livssituasion, behov, levemåte, sosial tilhørighet, psykiske og fysiske konstitusjon m.m. (se også Mehlum, 2005), men også den eksistensielle fengslingssituasjonen og den kriminelle handlingen. Motivene kan være tydeliggiorte eller mer skjulte, giennomtenkte eller mer uklare og innfløkte. I en gitt

\section{Selvmordene og selvmordstankene knyttes til fortvilelse, skammen og sorgen over å ha begått den kriminelle handlingen, men òg ved det å være i en makteslos og desperat situasjon isolert fra omverdenen.}

situasjon kan ett motiv være mer dominerende enn andre. Vi har skilt mellom for-å-motiver og fordi-motiver. For-å-motivene er framtidsrettet og giennomføres enten for å oppnå eller for å unngå noe. Fordi-motivene omfatter på-grunn-av-motiver og på-tross-av-motiver (Schütz, 2002). Vi har i tidligere teoretiske arbeider og på basis av våre empiriske studier analytisk delt selvmordene/selvmordsforsøkene inn i fem kategorier: 1) Selvmord eller selvmordsforsøk som beskyttelse, 2) som hevn eller giengieldelse, 3) som press, 4) som offer eller oppofrelse, 5) eller som en æressøkende handling (Hammerlin og Enerstvedt, 1988; Hammerlin og Schjelderup, 1994; se også Baechler, 1979; Hammerlin,
2009; Hammerlin og Leer-Salvesen, 2014). Også våre studier av selvmord og selvmordsnærhet i fengslene bygger på denne kategoriseringen og er sett i lys av den empirien vi har hatt tilgang på. Fra 1980-tallet har vi bygd på flere kilder som blant annet ulike fengselsdokumenter, hendelsesrapporter, eventuelle avskjedsbrev, massemedienes dekning eller uttalelser fra personalet og andre. Aktuelle informasjoner har vi også fått fra fengslene og fra Kriminalomsorgens sentrale forvaltning (KSF) og Kriminalomsorgsdirektoratet (KDI). Analysegrunnlaget omfatter i tillegg diverse delstudier der vi har hatt samtaler med fanger som hadde vært svært selvmordsnære eller slitt med store eksistensielle og helsemessige problemer (Hammerlin og Bødal, 1988; Hammerlin og Larsen, 2000; Hammerlin og Mathiassen, 2006; se også Hammerlin, 2009). Jeg har samlet sett kategorisert og generert motivene eller beveggrunnene over tidsspennet særlig fra 1956 til tidlig på 2000-tallet på følgende måte:

Selvmord som beskyttelse mot noe eller noen, det å beskytte seg mot en situasionell overbelastning, en konkret plagende og truende hendelse, ulike tap eller sosiale og helsemessige problemer synes å være det hyppigst nevnte motivet for den gruppa der vi har kjennskap til eventuelle beveggrunner for selvmordet (også for selvmordsforsøk). I samtaler som vi har hatt med fengslede og personalet over flere år i forbindelse med eksistensielle og fengselsmessige belastninger, konkretiseres beskyttelsesmotiv særlig i forbindelse med selvmordsforsøk, selvskader, selvmordstanker og andre eksistensielle kriser. Det fortelles om hvordan de selvmordsnære tynges av en grunnstemning av livsmatthet der de tappes for energi, og det fortelles om søvnløshet, dårlig matlyst, depresjoner, tanke- og konsentrasjonsproblemer. Noen er svært utmattet etter arrestasion og krevende forhør. Selvmordene og selvmordstankene knyttes til fortvilelse, skammen og sorgen over å ha begått den kriminelle handlingen, men òg ved det å være i en maktesløs og desperat situasion isolert fra omverdenen. Svært mange forteller om resignasjon, nedstemthet og håpløshet, men også om angst og pessimisme for situasionen, dommen og framtida. At forholdet til utenverden, familie, venner og andre flises opp eller opphører ved fengslingen er en stor påkjenning. Atskillige fanger med stoff- og alkoholproblemer er svært forkomne etter perioder med intensiv stoffbruk og er derfor utbrente og syke når de varetektsfengsles. Særlig abstinensproblemer og avbrudd i medisinering oppleves uutholdelig smertefullt. Enkelte er òg livredde for represalier etter å ha angitt andre. Behovet for å dø, eller markere døden som mulighet, motiveres ved å oppheve en plagsom, truende, knugende, kaotisk og smadret livssituasion, men også tap av integritet, tap av betydningsfulle andre, tap av frihet, tap av posisjoner med mer nevnes (jf. Fangenes tapsliste). Andre viser særlig til varetektsisolasionen og til fengslingens maktog tvangsstrukturer, og oppgir krenkelser, hjelpeløshet, 


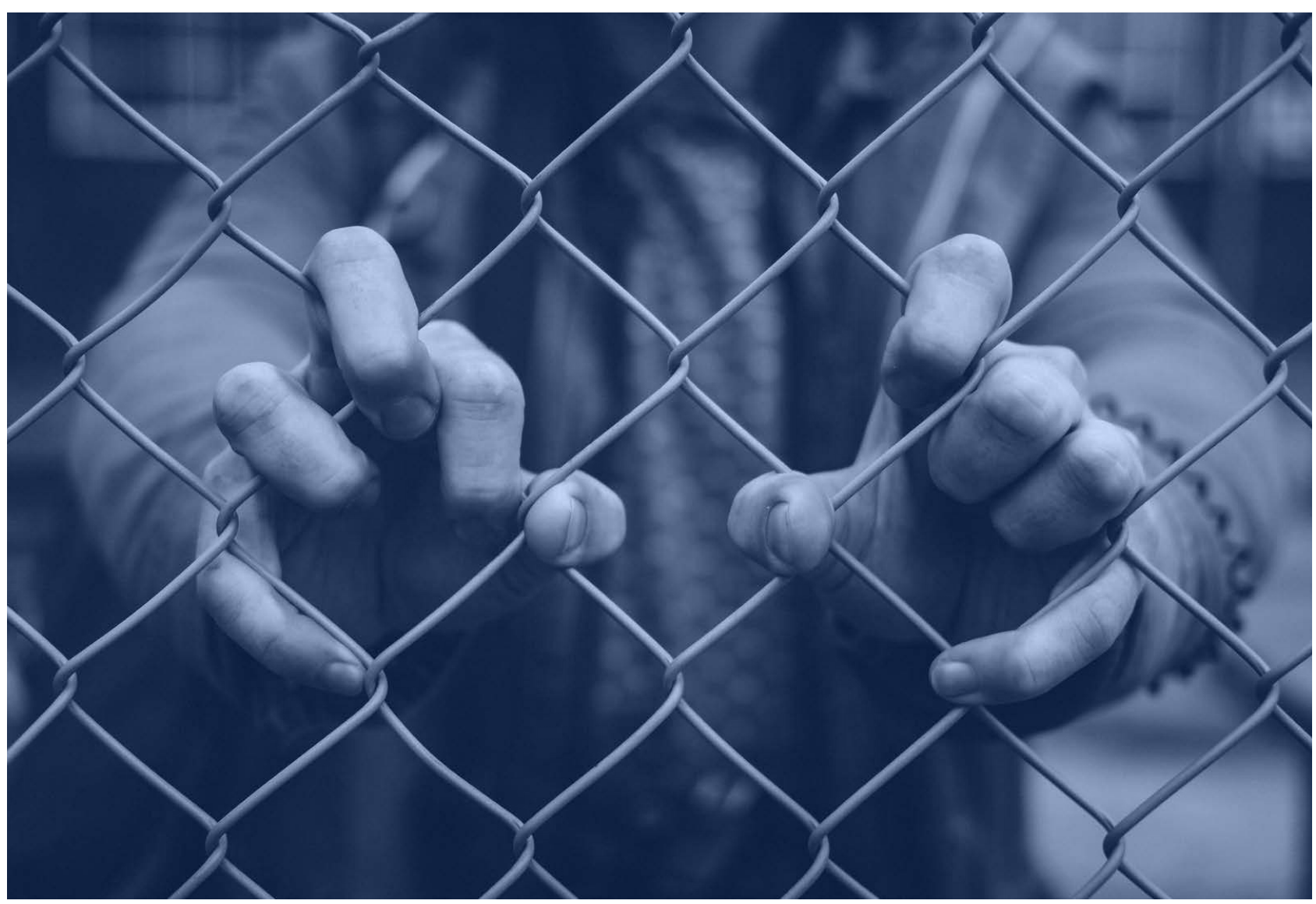

avmakt, fengslingens sosiale isolasjon, utrygghet, relasjonsbrudd, usikkerhet i livssituasionen, eksistensielle belastninger og angst for framtida som motiv (se også oversikter i Hammerlin, 2009).

Noen få har hatt hevn eller giengieldelse som motiv for selvmordshandlingen. Dette kan være rettet mot «systemet», grupper eller mot personer der målet har vært å påføre andre en belastning eller et diskvalifiserende stigma som giengjeldelse fordi de har følt seg krenket. Likevel, fra 1956 til 200o-tallet er det kun et par kjente eksempler på hevn- eller giengieldelsesselvmord.

Enkelte selvmordshandlinger har karakter av å være et pressmiddel. Noen fengslede er så sterkt omsorgs- og behandlingstrengende at de i desperasjon og fortvilelse over ikke å få adekvat hielp bruker selvmordhandlinger, selvskading og trusler om slike handlinger som pressmiddel. Mange av de behandlingstrengende er også i en «kasteballsituasjon» mellom psykiatrien og fengsel. Enkelte viser også til rettigheter som ikke følges opp.

Selvmordshandlinger kan begrunnes også som en oppofrelse - en selvmordsform ikke ulik Durkheims altruistiske selvmord. Flere sliter med skyldfølelse og selvbebreidelser og forteller at de er fortvilet over å ha sviktet familie og venner. Ikke sjelden har de utfort overgrep mot familie eller venner og ofte i ruspåvirket tilstand. De vil bryte livet fordi de ikke vil være til belastning for gienlevende. Noen har formidlet giennom avskjedsbrev at de bryter livet for ikke å være til belastning for egen eller offerets familie.

Enkeltes selvmordshandlinger kan betegnes som æressøkende. Personen søker da å gienvinne respekt og ære (særlig ut fra en sterk kulturrelatert æreskodeks).

\section{Noen utfordringer, noen kritiske strøtanker}

Flere problemer som jeg tar opp avslutningsvis er like aktuelle i dag som de var på 1980-tallet da Kåre Bødal og jeg skrev de første selvmordsrapportene. Andre problemer er mer situasjons- og tidsbetinget. Vi har publisert flere studier, rapporter, hefter og bøker om fengsels-selvmordsproblematikken som omfatter tidsspennet 1956-2015/2016. Siden 1980-tallet har vi også hatt selvmordsregistreringen som en departemental spesialoppgave.

Jeg starter med et etisk problem som jeg kaller skammens praksis: At sterkt hielpe- og behandlingstrengende og svært psykisk lidende fanger (bl.a. kronisk suicidale og atskillige selvskadende) er blitt og blir det som betegnes som «kasteball» mellom psykiatri og fengsel, er uverdig og inhumant. Jeg stiller derfor spørsmål (som vi har registrert helt fra 1980-tallets studier til nåtid) om hvilket menneskesyn og hvilken etikk som råder når helseinstitusjoner og psykiatriske institusjoner returnerer svært syke, selvskadede og selvmordsnære 


\section{leg vil betegne det som etisk stotende og kritikkverdig når svært omsorgs- trengende, behandlingstrengende og psykisk lidende fanger blir kasteball mellom psykiatriske institusjoner og fengslene.}

mennesker til en ny runde med fengselsinstitusjonelle belastninger. Dette avspeiler, etter min mening, en kynisk logikk som må kritiseres ut fra etiske og fagetiske prinsipper. I tråd med dette mener jeg at det nå er behov for å foreta grundige studier av rutinene som praktiseres og av den behandlingen (eller eventuell mangel på adekvat behandling) mange selvmordsnære fanger får i psykiatrien (eller helseinstitusjoner) for de returneres til fengslene. Jeg vil betegne det som etisk støtende og kritikkverdig når svært omsorgstrengende, behandlingstrengende og psykisk lidende fanger blir kasteball mellom psykiatriske institusjoner og fengslene. Svært kritisk er jeg også til den formidlingsformen og begrunnelsen som angivelig ble gitt fra enkelte psykiatriske institusjoner i forbindelse med retur av svært behandlingstrengende fanger: Fra to fengsler fikk jeg for kort tid siden tilbakemelding om at de hadde fått beskjed om at de aktuelle tilbakesendte fangene var «ubehandlbare» eller «ikke var behandlingsbare». Hvor vanlig er denne uttrykksformen? Det har jeg ikke undersøkt. Men betegnelsene skurrer faglig som etisk. Hvis dette er begrunnelser og betegnelser som brukes nå, er de etter min mening svært kritikkverdige: For det første fordi hjelpe- og omsorgsbehovet ikke følges opp fordi fangene sendes tilbake. For det andre fordi formidlingsmåten etter min mening avspeiler et fremmedgiørende, tingliggiørende og teknokratisk menneskesyn. Riktignok finnes det psykiske lidelser som man ikke har en effektiv behandling for. Men dette kvalifiserer ikke faglig og etisk for at fengslede mennesker sendes tilbake til fengslene og til nye lidelser. Problemstillingen er gammel - i alle studiene siden 1980-tallet har vi kritisert denne fatale og uverdige praksisen. Også slike avgiørelser må etterprøves faglig og etisk. Vi må snart erkjenne at enkelte mennesker sliter så mye eksistensielt og helsemessig at de ikke skal være i fengsel. I våre mange studier har vi også merket oss at enkelte sendes fort tilbake fordi de betegnes som farlige og voldelige. Også slike avgiørelser må etterprøves faglig og etisk.

At helseavdelinger i fengslene, helseinstitusioner og psykiatriske institusjoner også kan være faglig uenige om innleggelser, kan også true liv og helse. Jeg synes òg at mange eksterne helsearbeidere utenfor fengselsetaten kan altfor lite om fengselssystemet og fengslingens skadevirkninger.
Jeg stiller også et prinsipielt spørsmål om fangers behandlings- og pasientrettigheter sikres godt nok. Og hva med de fengsledes rettssikkerhet i forbindelse med eventuell feilbehandling (eventuelt ikke-behandling) - er den rutinemessig sikret? Hvilken tilgang har fangene på pasientombud? Jeg er enig med L. Mehlum som stiller spørsmål om nåværende omsorgsmodell for fanger med store psykiske lidelser er egnet; man mangler et mer adekvat omsorgsledd med flere behandlingsplasser, og da organisert innenfor helsevesenet (se også Mehlum, 1999; Hauge og Hammerlin, 1999). Det er for få plasser i dag, og fengslede blir sendt for raskt tilbake på tross av behovet for en bedre behandlingsmessig oppfølging (se også Rua, 2012; Hammerlin, 2016). Fengsler er òg blitt kritisert av helsesektoren, helsearbeidere og andre for at de ikke har fulgt godt nok opp enkelte fanger som er i eksistensiell og helsemessig krise. Også informasjons- og kommunikasjonsrutiner og informasjonspraksis på ulike nivåer i systemet har vist seg for dårlig ved flere hendelser. Det er etter min mening også et brudd på grunnleggende etiske fordringer om en human kriminalomsorg, og visst kan det være et uttrykk for dårlig fangebehandling og grunn til systemkritikk (Hammerlin, 2009). Men det er òg et resultat av en politisk-økonomistisk logikk som styrende prinsipp ved at fengslene utsettes for krav om strenge budsjettbesparinger og effektiviseringer av ressursbruken. Fra fengslene hevdes det at konsekvensene blant annet blir nedslitte fengsler, okt arbeidspress på betientene, begrenset tid til omsorgsarbeid, færre positive tiltak for fangene, mer og lenger innlåsing og for dårlig bemanning og stillingsoppdekninger. Det selvmordsforebyggende arbeidet i fengsel må derfor òg relateres til de politisk-økonomiske beslutningene og disposisjonene. I og med at de okonomiske betingelsene blir dårligere, får fengslene mindre ressurser til omsorgsarbeidet i fengselshverdagen - dette er prekært ikke minst overfor den fengslede som sliter med store eksistensielle og helsemessige problemer. Fengslene sliter også ressursmessig med at enkelte fanger er svært selvmordsnære og trenger mye oppfølging og omsorg, følgelig svekkes innsatsen for andre fanger som sliter. Dette er ikke minst et politisk ansvar.

En fortsatt utbredt misforståelse er at enkeltselvmord kan predikeres. Vi har registrert at slike misforståelser og risikovurderinger i form av skjematiske registreringer kan føre til falsk trygghet fordi det rettes for mye fokus på bestemte risikokarakteristika som dermed kan ta oppmerksomheten fra andre viktige forhold. Et annet problem er at prosessen ikke fanges opp, og en tilstand som oppfattes som ikke-suicidal i én situasjon, kan bli til en katastrofal feilslutning i en annen (Hammerlin, 1992; 2009; Medlicott, 2001). Uten tvil må informasjons- og kommunikasjonsstrukturen mange steder bli bedre. Men særlig viktig er samvirket og den omsorgen som gis i fengselshverdagen og da med adekvate hielpe- og omsorgstiltak ut fra et subjekt- 
perspektiv og en anerkjennelse av personens integritet og situasjonelle sårbarhet. Det dreier seg om å se mennesket i fengsel i et helhets- og førstepersonsperspektiv.

Gjennom forskningen vår har vi en omfattende og detaljert kunnskaps- og erfaringskapital om selvmord i norske fengsler. Spørsmålet er om og hvordan denne kunnskapen brukes. Den må anvendes mer av den sentrale fengselsledelsen, praksisfeltet og av helsepersonell. KRUS har imidlertid i sitt undervisningsopplegg for betjentaspirantene fulgt opp ulike opplegg for kompetansegivende tiltak. Men fra midten av 1990tallet har tendensen vært at What Works-ideologien har overskygget What-Hurts-perspektivet for mye i undervisningen (Hammerlin, 2004a; 2008; 2018/2019).

Varetektsinstituttet er knapt forandret på 130 år. Varetektinstituttet og bruk av isolasjon som praksisformer må nå evalueres og studeres kritisk i alle ledd i straffesystemet (domstolenes, påtalemyndighetenes og fengslets praksisformer), og isolasjonen slik den praktiseres, må opphøre.

Selvmordsproblematikken i fengslene må studeres på samfunnsnivå, fengsels- og avdelingsnivå - samt på gruppe- og individnivå. Suicidologiens flerfaglighet må sikres og brukes. Det er et problem at selvmordsproblematikken i kriminalomsorgen for ofte blir forstått som bare eller nesten bare et psykiatrisk og psykologisk problem. Undersøkelsene våre avdekker et problembilde som viser at selvmordsproblematikken er mangefaktoriell og kompleks og må løses tverr- og flerfaglig. Reduksjonistisk faghegemonisme må unngås: Sosiologisme, psykologisme, psykiatrisme, biologisme og kognitivisme er stikkord for faglig megalomani og provinsialisme. Benny Karpatschof (2013), som hadde ansvaret for metodeundervisningen i psykologi ved København universitet i over 40 år, har advart mot reduksjonismen i psykologien (hans kritikk gielder selvsagt også andre fagdisipliner og faglige skoleretninger). Han betoner at når psykologer er faglig provinsielle eller bornerte, så holder de seg innenfor deres eget gienstandsområde og forhindrer «deres fag i at interagere og kommunikere med nabovidenskaber om fælles emner. Og det er jo netop i grænseområderne, at nogle af vigtigste opgaver ligger.» Når psykologene er megalomane «så bilder de sig ind, at psykologien kan besvare langt flere spørgsmål end tilfældet er. Det vil ofte være som psykologisme, dvs. reduktionisme mht. behandlingen af samfundsvidenskabelige spørgsmål. Men det kan også være inden for etikkens område i form af den såkaldte naturalistiske fejlslutning.» (Karpatschof i Hammerlin, 2015b, s. 191). Karpatschofs innspill er viktig for det selvmordsforebyggende arbeidet som forutsetter det faglige mangfoldets potensiale.

Menneskesynet i fengselsvesenet avspeiler historisk sett et motsetningsforholdet mellom straffe- og omsorgsideologien, men de systemkritiske studiene jeg har foretatt avdekker også motsetningen mellom et objekt- og subjektperspektiv i rehabiliterings- og omsorgsarbeidet
(Hammerlin, 2004; 2008; 2019 in print; Hammerlin og Larsen 2000; Nygren og Fauske, 2010; Nida-Rümelin, 2016). Generelt sett har jeg òg kritisert at altfor mange omsorgs- og hjelpetiltak i årenes løp har redusert den enkelte til å være objekt for tiltak innenfor svært paternalistiske rammer (vi-vet-best-for-deg-perspektivet), men også for å ha vært for systemrettete og systemtilpassete framfor å bygge på et subjektperspektiv og den enkeltes konkrete livssituasjon. Anerkjennelsen av den enkelte som handlende og skapende subjekt må styrkes og er en forutsetning for personorienterte og persontilpassede hjelpe- og omsorgsopplegg (Hammerlin, 2008; 2009; 2018; Juul Jensen m.fl., 1996; Honneth, 2000; 2003; 2006; Høilund \& Juul, 2005; Thorgaard m.fl., 2010; Nygren \& Fauske, 2010). Men som mange fanger også har fortalt: Hvis det ikke hadde vært for omsorgsfulle medfanger, betjenter og andre aktører (også fengselsprestene nevnes ofte) «hadde jeg ikke klart meg».

\section{REFERANSER}

Alvarez, A. (1976). Den grymma guden. Stockholm: Rabén \& Siögren.

Andersen, H.S., Lillebæk, T. \& Sestoft, D. (1994). Isolationsundersøgelsen. Varetektfængsling og psykisk helbred. Bind 1 og II. København: Bisbebjerg Hospital \& Retspsykiatrisk klinik.

Andersen, H.S., Lillebæk, T., Sestoft, D. (1997). Efterundersøgelsen - en opfølgingsundersøgelse af danske varetægtsarrestanter. København: Bisbebjerg Hospital \& Retspsykiatrisk klinik.

Andenæs, I. (1974). Alminnelig strafferett. Oslo: Universitetsforlaget.

Baechler, I. (1979). Suicides. Oxford: Basil Blackwell.

Benjaminsen, S. \& Erichsen, B. (2002). Selvmords-adfærd blant indsatte. København: Kriminalforsorgens uddannelsescenter.

Beskow, I. (2005). Suicidalitet som språk. I: Herrestad, H., Mehlum, L. (red.). Uutholdelige liv. Om selvmord, eutanasi og behandling av doende. Oslo: Gyldendal Akademisk, s. 43-59.

Betækning om varetægtsfængsling $i$ isolation. Afgivet af Justisministeriets Strafferetsplejeudvalg. Betænkning $n r .1358,1998$.

Brekke, E., \& Halvorsen, G. (2004). Soning av straff i fengsel - den innsattes opplevelse. Oslo: Psykologisk Institutt, Universitetet i Oslo.

Temarapport. (2012). Bruk av isolasjon i fengsel. Norsk lov og praksis $i$ et menneskerettslig perspektiv. Oslo: Nasjonal institusion for menneskerettigheter ved UiO. Norsk senter for menneskerettigheter/Det juridiske fakultet.

Bukten, A. m-fl. (2017). High risk of overdose death following release from prison: Variations in morality during a 15 -years old observation period. Addiction 112(8), 1432-1439, dol:10.1111/add.13803.

Christie, N. (1982). Pinens begrensning. Oslo: Universitetsforlaget/Chr. Ejlersforlag.

Clausen, S. (2013). Klientundersøgelsen. København: Kriminalforsorgen.

Cramer, V. (2014). Forekomsten av psykiske lidelser hos domfelte i norske fengsler. Oslo: Kompetansesenterets Prosiektrapport 2014-1/Helseregion Sor-Øst.

Critchley, S. (2015). Notes on Suicide. Fitzcarraldo Editions.

Danielsen, T. \& Karlsen, V. (2007). Kvalitet i varetektsarbeidet. Oslo: KRUS.

Dagbladet Information. (Artikkelen «Sejlivet isolation» 09.12.2005). 
Dyb, E., Brattbakk, I., Bergander, K. \& Helgesen I. (2006). Loslatt og hiemlos. Oslo: NIBR/Byggforsk/KRUS.

Forebygging av selvmord i Oslo fengsel. En arbeidsgrupperapport. Oslo fengsel 8.5.2014.

Foucault, M. (2002). Overvågning og straf. Fængslets fødsel. København: Det lille forlag.

Fridhov, I.M. (1993). Klient i friomsorg 1992. Oslo: Dokumentasion \& debatt/93/KRUS.

Friestad, C. \& Hansen, L.S. (2004). Levekår blant innsatte. Oslo: Fafo-rapport $/ 429$.

Gamman, T. (1995). Uheldige helsemessige effekter av isolasion. I Tidskr. for Norsk Lægeforening nr.18 (115).

Hammerlin, Y. (1994). Tidsglimtet - et fengselssystem eller kriminalomsorg i endring. I: Festskrift til Kåre Bødal 1994. Oslo: KRUS/Krim.oms.avd. Justisdep., 87-102.

Hammerlin, Y. (1999). Samfunnets lidelsesproduksion. Ansatser til en kritisk ettertanke. I: Beskow, I., Eriksson,B.E., Nikku, N. (red) Självmordsbeteende som språk. Stockholm: FRN Forskningsrådsnämden , s. 213-252.

Hammerlin, Y. (2004a). Omsorg og behandling - men også sublime metoder fors sosial kontroll og underkastelse i et repressivt system? I Psyke \& logos, 25, s. 697-727.

Hammerlin, Y. (2008). Om fangebehandling, fange- og menneskesyn i norsk kriminalomsorg $i$ anstalt 1970-2007. Oslo: Det juridiske fakultet/Inst.for kriminologi og rettssosiologi/Universitetet i Oslo.

Hammerlin, Y. (2009). Selvmord og selvmordsnærhet i norske fengsler/ Selvmordforebyggende arbeid i fengsel. Oslo: KRUS-håndbøker nr. 3/2009.

Hammerlin, Y. (2010a). Å bryte livet i fengsel. Suicidologi 15 (2), Oslo: Nasjonalt senter for selvmordsforskning og - forebygging, Universitetet $i$ Oslo, s. 20-29.

Hammerlin, Y. (2010b). Samfunnets og hverdagslivets lidelsesproduksion og selvmordsproblematikken. Ansatser til en kritisk refleksjon. Suicidologi 15(2), Oslo: Nasionalt senter for selvmordsforskning og -forebygging, Universitetet $i$ Oslo, s. 30-36.

Hammerlin, Y. (2012). En fange er en fange - et fengsel er et fengsel. Dikotomien i fangebehandlingen fra 1950-tallet fram til i dag. I: Olsen, S.: Virker straff? Oslo: Scandinavian Academic Press., s. 39-62.

Hammerlin, Y. (2015a). «Et fengsel er et fengsel, men ...». I Psyke \& Logos. København: Dansk Psyk. Forlag, 36, s. 129-152.

Hammerlin, Y. (2015b). Å bryte livet i fengsel. I Psyke \& Logos. Dansk Psyk. Forlag, 36, s. 174-194.

Hammerlin, Y. (2016). Et kritisk sideblikk på forebyggingsarbeidet i fortid, nåtid eller framtid. Suicidologi 21(1), 35-42.

Hammerlin, Y. (2019). Hard mot de harde, myk mot de mye. Oslo: Universitetsforlaget (In print).

Hammerlin, Y. \& Bodal, K. (1988). Selvmord i norske fengsler 1956-1987 [del $10 \mathrm{~g}$ 2]. Oslo: Justisdepartementet. Del II var en rapport basert på kasuistikk og samtaler med selvmordsnære fanger.

Hammerlin, Y. \& Bødal, K. (1991/1992). Selvmord i norske fengsler 1956-okt. 1992. Oslo: KRUS-rapport.

Hammerlin, Y. \& Enerstvedt, R.T. (1988). Selvmord. Oslo: Falken forlag.

Hammerlin, Y. \& Schielderup, G. (1994). Når livet blir en byrde. Oslo: Gyldendal Ad Notam.

Hammerlin, Y. \& Larsen, E. (1997/2002). Menneskesyn i teorier om mennesket. Oslo:Ad Notam/Århus: KLIM.

Hammerlin, Y., \& Larsen, E.(2000). Tungtsonende. Oslo: KRUS/Dokumentasjon \& debatt $n$ r. 2/2001.

Hammerlin, Y., Kristoffersen, R. (1998). Habilitering som livsmestringsprosess. Oslo: Dokumentasion \& debatt/Nr. 1/98/KRUS.
Hammerlin, Y. \& Mathiassen, C. (2006). For og nå. Oslo: Rapport/5/2006/ KRUS.

Hammerlin, Y. Hammerlin, Y., Leer-Salvesen, P. (2014): Voldens ansikter - en dialog om ondskap, ansvar og håp. Oslo: Cappelen Damm Akademisk.

Hammerlin, Y.\& Grav, F. (2015/2016). Internrapport om selvmord i norske fengsler 2000-2014. Oslo: KRUS/KDI.

Hartvig, P. \& Ostberg, B. (2004). Psykisk lidelse og avvik blant norske fengselsinnsatte. Tidsskrift for Den norske Lægeforening, 124, 2091-2093.

Hauge, N.-P., Hammerlin,Y. (1999). Selvmordsforebygging i et helhetlig perspektiv. I: Mehlum, L. (red.): Tilbake til livet. Kristiansand: Hoyskoleforlaget.

Herrestad, H., Mehlum, L. (red.) (2005). Uutholdelige liv. Oslo: Gyldendal Akademisk.

Honneth, A. (2000). Das Andere der Gerechtigkeit. Aufsätze zur Praktischen Philosophie. Frankfurt am Main: Suhrkamp.

Honneth, A. (2003). Behovet for anerkendelse. København: Hans Reitzels forlag.

Honneth, A. (2006). Kamp om anerkendelse. Kobenhavn: Hans Reitzels forlag.

Hytten, M. (2012). Tid i varetekt. En undersøkelse av varetektsinnsattes tidsopplevelse. Oslo: Univrsitetet i Oslo/Inst. for kriminologi og rettssosiologi.

Hoilund, P. og Juul, S. (2005). Anerkendelse og dommekraft i socialt arbejde. Kobenhavn:Hanz Reitzels forlag.

Jensen, U.J., Qvesel, J.A., Fuur, P. (1996). Forskelle og forandring - bidrag til humanistisk sundhedsforskning. Ảrhus: Philosophia.

Karpatschof, B. (2006). Udforskning i psykologien. København: Akademisk forlag.

Karpatschof, B. (2013). Psykologismens sirenesang og psykologiseringens heksekunst. I Fortsatt i virksomhet. Festskrift til Regi Th. Enerstvedts 75 årsdag. Oslo: Sokelys 9/2013/Skriftserie for kultur og vitenskap. s. 42-70.

Kielsberg, E. og Hartvig, P. (2005). Sykdomsforekomst og behandlingstilbud for fengselsinnsatte. Undersokelser giennomfort i norske fengsler 2003-2005. Oslo: Kompetansesenteret, prosiektrapport 2005-3/Helse Sor.

Kielsberg, E., Hartvig, P., Bowitz, H., Kuisma, I., Norbech, P., Rustad, AB, Seem, M. \& Vik, TG (2006). Mental health consulations in a prison population: a descriptive study. I BMC Psychiatry 2006, 6:27.

Kielsberg, E. \& Sorland, T.O. (2009). Mental helse hos varetektsfengslede tenåringsgutter i Oslo. Tidsskrift for Den norske legeforening 129, $2472-2475$.

Kjelsberg, E. \& Laake, P. (2010). Is the high mortality risk in sentenced offenders independent of previous imprisonment? Eur I Epidemiol, 25 (4), 237-43.

Kristoffersen, R. (2013). Nytt om isolasion i fengsel. I: Rett på sak/ Aktualitetsmagasin for domstolene 2013 (1): s. 24-25.

Leer-Salvesen, P.L. (1988). Etter drapet. Oslo: Universitetsforlaget.

Leer-Salvesen, P.L. (2004). Drapet og selvmord: en etisk refleksjon. Suicidologi, 9 (1), S.13-15.

Levander S., Svalenus, H., Jensen,I. (1997). Psykiska skador vanliga bland interner. Läkartidningen, 94(1-2), s. 44-50.

Lillebæk, T. og Sestoft, D. (1997). Skizofrene varetægtsfængslede. Ph.d-avhandling. København: Justisminist, Retspykiatrisk Klinik.

Lillevolden, S. (2014, 17. mars). Avmaktens korridorer. Aftenposten, s. 4. Lillevolden, S. (2017). Når angsten tar fanger. I Festskrift til Yngve Hammerlin, OSLO: KRUS, S.108-112.

Mathiassen, C. (2004). Fanget $i$ tilværelsen? Casestudier i fastlåshed og forsog på frigorelse. Ph.d.-afhandling. Kobenhavn: Inst.for psykologi/Københavns universitet. 
Mathiassen, C. (2005). Fanget i tilværelsen. I Nordiske Udkast, nr. 2, 53-66. Mathiesen, T. (1978). Den skjulte disiplinering. Oslo: Pax forlag. Mathiesen, T. (1995). Kan fengsel forsvares? Oslo: Pax forlag. Mehlum, L. (red.) (1999). Tilbake til livet. Kristiansand:Hoyskoleforlaget. Mehlum, L. (2005). Om motiver og intensjoner ved selvmordshandlinger.. I Herrestad, H. \& Mehlum, L. (red.): Uutholdelige liv. Om selvmord, eutanasi og behandling av døende. Oslo: Gyldendal Akademisk, s. 29-41.

Medlicott, D. (2001). Surviving the prison place. Aldershot: Ashgate.

Metz, M., Seesslen (2017). Freiheit und Kontrolle. Berlin: Suhrkamp.

Nida-Rümelin, I. ( 2016). Humanistische Reflexionen. Berlin: Suhrkamp.

Nygren, P. \& Fauske, H. (2010). Handlekompetence og ideologi. København: Dansk Psykologisk forlag.

Nordisk Statistik 2008-2012. (Red. S. Hildebrandt). København: Dir. for Kriminalforsorgen.

Rasmussen, K., Levander, S. (1996). Symptoms and Personality Characteristics of Patiens in a Maximum Security Psychiatric Unit. Int.Journal of Law and Psychiatry, 19 (1), s. 27-37.

Revold, M. K. (2015). Innsattes levekår 2014. For, under og etter soning. SSB-rapport 2015/47.

Rein, I. (2009). Isolasjon. København: Inst.for psykologi.

Rua, M. (2012). Hva gior fengselsleger? Oslo: Inst. For kriminologi og rettsso siologi. Jurfakultet/Univ. I Oslo/Bokserie nr.1/2012.

Rundskriv, 29.12.1997 (Fengselsstyret/Iustisdep.): Behandling av varetekts innsatte - herunder særlige tiltak for varetektsinnsatte ilagt restriksioner.

Schaanning, E. (2009). Den tilsiktede smerten. En blindflekk i norsk kriminalpolitikk. Oslo: Unipub.

Scharff, P.S., Horn, T. Nilsen, I.T. \& Rua, M. (2013). Isolation i skandinaviske fængsler. Social Kritik 25 (136), s. 4-20.

Schütz, A. (2002). Den sociale världens fenomenologi. Uddevalla: Daidalos.

Selvskade. Temanummer. Psyke \& Logos nr.2 2016/årgang 37. København: Dansk Psykologisk forlag.

Skardhamar, T. (2002). Levekår og livssituasion blant innsatte i norske fengsler. Oslo: Institutt for kriminologi og rettssosiologi/K-serien nr. 1/2002.

Stang, I., Moe, I. Teigset, I.A., Ostberg, B. Moger, T.A. (2003). Fanger i sikkerhetscelle - en utfordring. I Medisin og vitenskap. Tidsskrift for Den norske legeforening, $n r .13^{-14}$

Sykdomsforekomst og behandlingstilbud for fengselsinnsatte (2005). Oslo: Kompetansesenteret, prosiektrapport 2005-3/Helse Sor.

Thorsen, L. (2004). Straffedes levekår og sosiale bakgrunn. Oslo: Inst.for kriminologi og rettssosiologi. Universitetet i Oslo.

Thorgaard, K., Jensen, U.J., Nissen, M. (red) (2010). Viden, virkning og virke - forslag til forståelser i sundhedspraksis. Roskilde Universitetsforlag.

Walby, F. (2004). Drap etterfulgt av selvdrap. Suicidologi, 9 (1), s. 10-12.

YNGVE HAMMERLIN er dr.philos, førsteamanuensis og forsker. Denne kronikken er en videreføring og oppfølging av tidligere fengselsstudier som Hammerlin har foretatt fra 1988 fram til i dag, særlig artiklene i Suicidologi i 2010 og Psyke \& Logos i 2015.

\author{
Kurset koster kr 3500. \\ $\mathrm{Da}$ er deltakelse, \\ materiell og lunsj \\ begge dager inkludert.
}

TEMA: Bli bedre til å anvende DBTferdighetene $i$ individualterapi og i gruppe slik at de passer den enkelte pasients utfordringer.

Kursets hovedforeleser er Jennifer Sayrs, Ph.D. Hun leder DBT Center i Seattle og jobber i tillegg ved BTECH, Linehan Institute. Sayrs er en erfaren DBT-lærer og har vært forskningsterapeut og adherencekoder i flere kliniske DBT-studier. I tillegg foreleser NSSFs førsteamanuensis Anita J. Tørmoen, Ph.D.

Les mer og meld deg på: www.dbt.no
DBT DIALEKTISK ATFERDSTERAPI 